Tsaqofiya : Jurnal Pendidikan Bahasa dan Sastra Arab

Vol. 3 No. 1, 2021, 16-25

P-ISSN : 2685-7022, E-ISSN : 2685-7103

DOI: $10.21154 /$ tsaqofiya.v3i1.65

\title{
Analisis Buku Bahasa Arab Pegangan Guru dan Siswa Kelas XI Kurikulum 2013
}

\author{
Mirwan Akhmad Taufiq1, Muhammad Nashrullah ${ }^{2}$ \\ ${ }^{1}$ UIN Sunan Ampel Surabaya, ${ }^{2}$ UIN Sunan Ampel Surabaya \\ mnshrljbg@gmail.com
}

\section{Abstract}

This study aims to explain the quality of the teacher's handbook and the student's handbook of Arabic book on XI class with curriculum of 2013 printed by the Ministry of Religion in Indonesia. The existence of books has a very important role in learning in schools. In this case, the quality of the textbooks that are used as learning resources also determines the results of the achievement of learning objectives. One of the government policies in implementing the curriculum of 2013 is the use of student's handbook that are equipped with a teacher's handbook. The approach in this research is descriptive qualitative (Library Research). The data in this study are related to the quality of teacher's and student's handbook. The source of the data was obtained from the textbooks of teachers and students of Arabic class XI curriculum of 2013 printed by the Ministry of Religion. Data collection techniques through documentation. Meanwhile, the data analysis technique is through clarification and description. Based on the analysis that has been done, the results of this study indicate that the quality of teacher and student textbooks is in the good category. However, there are several things that need to be completed, such as writing the address of the photo or image where it was obtained in the discussion of the material.

Key words: Arabic handbook analysis, teacher's handbook, student's handbook

\section{Abstrak}

Penelitian ini bertujuan untuk menjelaskan kualitas buku pegangan guru dan pegangan siswa "Bahasa Arab" kelas XI kurikulum 2013 cetakan Kementerian Agama. Keberadaan buku mempunyai peran sangat penting dalam pembelajaran di sekolah. Dalam hal ini, kualitas buku pelajaran yang dijadikan sumber pembelajaran ikut serta menentukan hasil pencapaian tujuan pembelajaran. Salah satu kebijakan pemerintah dalam menerapkan kurikulum 2013 adalah pengunaan buku pegangan siswa yang dilengkapi oleh buku pegangan guru. Pendekatan pada penelitian ini adalah deskriptif kualitatif (Library Research). Data dalam penelitian ini adalah terkait kualitas buku pegangan guru dan siswa. Sumber data didapatkan dari buku pegangan guru dan siswa Bahasa Arab kelas XI Kurikulum 2013 Cetakan Kementerian Agama. Teknik pengumpulan data melalui dokumentasi. Sedangkan teknik analisis data melalui klarifikasi dan deskripsi. Berdasarkan analisis yang telah dilakukan, hasil penelitian ini menunjukkan bahwa kualitas buku pegangan guru dan buku pegangan siswa termasuk pada 
kategori baik. Namun ada beberapa hal yang perlu di lengkapi seperti penulisan alamat foto atau gambar didapatkan dari mana dalam pembahasan materi.

Kata kunci: analisis Buku Bahasa Arab, buku pegangan guru, buku pegangan siswa

\section{Pendahuluan}

Buku merupakan salah satu bentuk bahan ajar yang dicetak dan merupakan bentuk bahan ajar yang paling banyak digunakan dalam proses pembelajaran. Secara garis besar bahan ajar mengandung isi yang substansinya meliputi tiga hal yaitu pengetahuan (fakta, konsep, prinsip dan prosedur), keterampilan dan sikap (nilai). Ketiga hal tersebut haruslah menunjang ketercapaian standar kompetensi dan kopetensi dasar yang telah ditentukan dalam pembelajaran. ${ }^{1}$

Buku teks adalah buku sekolah yang mengemban bahan ajar yang diseleksi mengenai studi tertentu dengan bentuk tertulisan yang memenuhi syarat tertentu dalam kegiatan belajar mengajar dan disusun secara terstruktur untuk diasimilasikan. Chambliss dan Calfee berpendapat buku teks adalah alat bantu siswa untuk memahami dan memberikan wawasan dari hal-hal yang dibaca untuk memahami dunia. ${ }^{2}$

Buku sebagai sumber belajar akan tetapi juga termasuk sebagai bahan ajar, yang dengan bahan ajar tersebut diharapkan siswa mampu mempelajari suatu kompetensi atau kopetensi dasar secara runtut dan sistematis sehingga secara akumulatif mampu menguasai semua kompetensi secara utuh. ${ }^{3}$ Di dalamnya terdapat materi pelajaran yang merupakan sarana penunjang tercapainya tujuan pembelajaran. ${ }^{4}$ Materi buku terlebih dahulu harus melalui seleksi, gradasi, presentasi dan repetasi. Sebelum dijadikan tujuan. Tujuan tersebut akan menjadi tolak ukur dalam perumusan materi. ${ }^{5}$

Dengan adanya buku yang berkualitas, Badan Standar Nasional Pendidikan (BSNP) telah mengembangkan beberapa komponen yang dijadikan landasan dalam

\footnotetext{
1 Andi Prastowo, Panduan Kreatif Membuat Bahan Ajar Inovatif (Yogyakarta: Diva Press, 2011).

2 Muslich Mansur, "Text Book Writing: Dasar-Dasar Pemahaman, Penulisan Dan Pemakaian Buku Teks," Jogjakarta: Ar-Ruzz Media, 2010, 50.

3 Abdul Majid, "Perencanaan Pembelajaran Mengembangkan Standar Kompetensi Guru," Bandung: PT Remaja Rosdakarya, 2008, 173.

4 Ahmad Mujib and Muhammad Noval Rikza, "Tadriis Al-Nahw Fii Dhau Al-Nadzhariyyat AlMa'rifiyyat Li Thullaab Al-Shaff Al-Raabi' Bi Ma'had Daar Al-Najaa Al-Islaamiyy Al-Salafiyy Ponorogo," Tsaqofiya: Jurnal Pendidikan Bahasa Dan Sastra Arab 1, no. 2 (2019): 69-84.

5 Acep Hermawan, "Metodologi Pembelajaran Bahasa Arab, Cet Ke-1, Bandung: PT," Remaja Rosdakarya, 2011, 107.
} 
telaah buku. Menurut BSNP, buku berkualitas wajib mempunyai empat komponen kelayakan yang meliputi kelayakan isi, kelayakan penyajian, kelayakan kebahasaan, dan kelayakan kegrafikan. Keempat komponen tersebut dijelaskan dalam beberapa indikator yang terperinci sehingga guru dapat mengaplikasikanya. ${ }^{6}$

Peran penting analisis buku diatas menunjukkan bahwa upaya analisis buku sangat penting untuk dilaksanakan. Pengabaian analisis buku bisa diartikan mengabaikan mutu pembelajaran. Keberadaan buku sebagai sumber belajar bisa memicu sumber masalah dalam pembelajaran. ${ }^{7}$ Ketidaktepatan yang ada dalam buku pegangan guru ataupun buku pegangan siswa tersebut dapat saja terjadi. Guru sebagai pemegang kendali di dalam pembelajaran di kelas perlu mencermati terlebih dahulu terhadap buku siswa ataupun buku pegangan guru yang sudah disediakan pemerintah. Buku tanpa dilakukan analisis terlebih dahulu pada akhirnya siswa yang menjadi korban. Berbagai kemungkinan dapat terjadi. Buku yang tidak sesuai standar kualitas dapat menjadikan kegagalan dalam menarik siswa untuk mempergunakan sehingga berdampak pada motivasi dan prestasi belajar siswa. ${ }^{8}$

Sebagaimana diketahui, telah banyak diberitakan pada media massa mengenai kasus buku yang menjadikan nilai negatif dunia pendidikan. Menyebarnya kasus tersebut member isyarat bahwa analisis buku harus dilakukan. Setelah melakukan identifikasi awal (pra-penelitian) terhadap buku Bahasa Arab pegangan guru dan siswa kelas XI kurikulum 2013 cetakan Kementerian Agama, ditemukan beberapa kelebihan dan kekurangannya.

Berdasarkan instrument penelitian buku teks yang ditetapkan oleh BSNP, peneliti akan menjelaskan bagaimana kualiatas buku Bahasa Arab pegangan guru kelas XI kurikulum 2013 cetakan Kementerian Agama, bagiamana kualitas buku pegangan siswa kelas XI kurikulum 2013 cetakan Kementerian Agama, Apakah sudah memenuhi kualitas buku teks yang ditetapkan oleh BSNP? Setelah merumuskan masalah peneliti perlu menuliskan tujuan penganalisisan, tujuan penganalisisan ini adalah untuk menjelaskan kualitas buku teks Bahasa Arab pegangan gurukelas XI

\footnotetext{
${ }^{6}$ Masnur Muslich, "Text Book Writing: Dasar-Dasar Pemahaman, Penulisan, Dan Pemakaian Buku Teks," Jogjakarta: Ar-Ruzz Media 52 (2010): 47-52.

${ }^{7}$ Muhimmatul Mukarromah, "Tathwiir Al-Kitaab Al-Madrasiyy Li Al-Qawaaid Al-'Arabaiyyat Li Thullaab Qism Ta'liim Al-Lughat Al-'Arabiyyat Bi Al-Jaami'ah," Tsaqofiya: Jurnal Pendidikan Bahasa Dan Sastra Arab 1, no. 2 (2019): 51-68.

${ }^{8}$ Henry Guntur Tarigan and Djago Tarigan, Telaah Buku Tekst Bahasa Indonesia (Angkasa, 1986).
} 
kurikulum 2013 cetakan Kementerian Agama, menjelaskan kualitas pegangan siswa kelas XI kurikulum 2013 cetakan Kementerian Agama, Apakah sudah memenuhi kualitas buku ajar yang ditetapkan oleh BSNP.

\section{Metode}

Sesuai dengan permasalahan, penelitian ini mengunakan metode kualitatif sebagai prosedur penelitian ini, yang menghasilkan data diskriptif berupa kata-lata tertulis dengan jenis penelitian kepustakaan atau Library Research yang memanfaatkan sumber kepustakaan untuk memperoleh data penelitian. ${ }^{9}$

Tentunya produr penelitian ini tidak dapat diekspresikan dengan statistik atau cara-cara kuantifikasi. Sumber data penelitian ini adalah kualitas buku teks Bahasa Arab pegangan guru dan pegangan siswa kelas XI kurikulum 2013 cetakan Kementerian Agama.

\section{Buku Ajar}

Yang dimaksud dengan buku ajar yaitu buku yang dijadikan pedoman siswa pada jenjang tertentu sebagai media pembelajaran, yang berkaitan dengan mata pelajaran tertentu. Buku ajar adalah buku yang diterbitkan oleh para pakar dalam bidangnya, yang dilengkapi dengan sarana pembelajaran dan digunakan sebagai pendukung program pembelajaran. ${ }^{10}$

Direktorat Pendidikan Menengah Umum menyebutkan buku ajar adalah sekumpulan tulisan yang dibuat secara terorganisir, berisi materi pelajaran tertentu yang disiapkan oleh pengarangnya, kurikulum yang berlaku sebagai acuannya. Substansi yang ada dalam buku diturunkan dalam kompetensi yang wajib difahami oleh pembacanya. ${ }^{11}$

Dari definisi di atas dapat disimpulkan buku ajar merupakan bagian bahan ajar yang didalamnya terdapat materi yang mendukung untuk sampai pada tujuan pembelajran yang dirancang oleh para ahli secara sistematis. Adapun sistemasi penulisan buku ajar di Indonesia telah diatur oleh badan khusus yang dikenal dengan

\footnotetext{
9 J Moleong Lexy, “Metodologi Penelitian Kualitatif," Bandung: Remaja Rosdakarya, 2002.

10 Pusat Perbukuan, Pemilihan dan pemanfaatan buku teks pelajaran yang memenuhi syarat kelayakan (Jakarta: Pusat perbukuan departemen pendidikan nasional, 2006) hal. 1.

11 Direktorat pendidikan menengah umum, Pedoman memilih buku SMA (Jakarta: Direktorat Pendidikan Menengah Umum, Direktorat Jendral Manajemen pendidikan dasar dan menengah, departemen pendidikan nasional, 2004) hal. 3.
} 
BSNP (Badan Standar Nasional Pendidikan). Hal ini dilakukan untuk mengawasi peredaran buku-buku yang banyak diterbitkan oleh penerbit-penerbit buku di Indonesia.

\section{Buku Pegangan Guru dan siswa}

Buku pelajaran Bahasa Arab kelas XI kurikulum 2013 cetakan Kementerian Agama, terbagi dalam dua jenis yaitu buku pegangan guru dan buku pegangan siswa. Kedua buku itu bersifat saling melengkapi. Berjalan selaras dalam pembelajaran didalam kelas, mengingat guru dan siswa memiliki pola yang sama dalam mengembangkan materi pembelajaran. Kementerian Agama menerbitkan sebuah paket yang terdiri dari buku teks pegangan guru dan buku pegangan siswa yang digunakan pada kelas XI diseluruh Indonesia yang telah mengimplemasiakan kurikulum 2013.

\section{Buku Ajar dalam Standar BSNP (Badan Standar Nasional Pendidikan)}

Sehubungan dengan penilaian buku ajar, BSNP telah mengembangkan instrument penilaian buku ajar. Instrument tersebut dipakai dalam menentukan kelayakan sebuah buku ajar untuk dapat dikategorikan sebagai buku standar. BSNP menyatakan buku ajar yang berkualitas harus mempunyai empat unsur kelayakan, yaitu unsur isi, unsur penyajian, unsur kebahasaan, dan unsur kegrafikan.

- Unsur isi

Unsur isi berkaitan dengan tiga hal:

1) Keselarasan uraian materi antara KI dan KD yang terdapat pada kurikulum yang berlaku

2) Keakuratan materi (keakuratan dalam pemilihan wacana, konsep, teori, contoh dan latihan)

3) Materi pendukung penyajian, yaitu kesesuaian dengan perkembangan ilmu, sesuai dengan perkembangan ilmu pengetahuan, dan relevan dengan tingkat kognisi anak didik.

Kelayakan isi berkaitan dengan materi yang disajikan. Aspek isi atau materi tidak boleh keluar dari aspek-aspek berikut: a) mendukung isi pokok bahasan; b) kebenaran dan kelengkapan materi; c) sistematika; d) penyajian menarik dari 
sederhana ke kompleks, mudah dipahami serta mendorong keaktifan siswa untuk belajar. ${ }^{12}$

- Unsur penyajian

Penyajian adalah sesuatu itu dikemas. Sesuatu meskipun bernilai tinggi jika dikemas tidak baik, tidak teratur, dan tidak runtut, tentunya akan menjadikan yang baik tersebut itu tidak menarik.

Unsur penyajian meliputi; 1) rancangan yang dipakai dalam buku harus menunjukkan rancangan yang disarankan kurikulum, 2) lingkup dan urutan harus dirancang secara logis mulai dari sisi logis, mulai dari sisi yang lazim bagi siswa baru kemudian diikuti oleh subjek yang baru, kompleks dan abstrak, 3) saling memperkuat dengan bahan kajian yang terkait, 4) menarik minat dan perhatian siswa, 5) menstimulus siswa untuk terus mempelajari bahan kajian pelajaran yang bersangkutan, 6) penyampaian termasuk penataan bahan pelajaran dan sitematika penulisan berpedoaman pada berbagai aspek kemampuan dan tingkat perkembangan siswa. ${ }^{13}$

- Unsur kebahasaan

Bahasa adalah isi pokok dalam memahami buku ajar. Unsur bahasa berkaitan dengan tiga hal:

1) Kesesuaian bahasa dengan tingkat perkembangan siswa

2) Pemakaian bahasa yang komunikatif

3) Pemakaian bahasa memenuhi syarat dan alur keruntutan dan keterpaduan

Hal-hal yang perlu diperhatikan dari aspek kelayakan bahasa meliputi; 1) pengunaan bahasa Indonesia yang baik dan benar, serta mudah dipahami, 2) pemilihan kosa kata (istilah, pilihan kata, dan ejaan). Struktur kalimat, pengaturan alinea dan paragraph, 3) pengalihan huruf harus menggunakan transliterasi yang dibakukan.

- Unsur kegrafikan

12 Dedi Supriadi and Hermawan S Nugroho, Anatomi Buku Sekolah Di Indonesia: Problematik Penilaian, Penyebaran, Dan Penggunaan Buku Pelajaran, Buku Bacaan, Dan Buku Sumber (-, 1919), 176-77.

13 Departemen Pendidikan Nasional, Pedoman Memilih dan Menyusun Bahan Ajar, (Jakarta: Dirjen Pendidikan Dasar dan Menengah, 2006), Hal. 4. 
Unsur kegrafikan memiliki beberapa hal; ukuran buku dan jenis kertas, desain kulit buku dan desain isi buku. Aspek grafika yang wajub diperhatikan; tipografi (jenis huruf, korp, spasi lebar susunan dan bentuk susunan), tata letak (pola atau margin, keseimbangan dan kesesuaian), kualitas cetak (kerataan tinta, kerapatan cetak dan cetak tembus), kualitas penyelesaian (pegeleman, jahitan, pelipatan dan pemotongan), ilustrasi (jenis, daya tarik, anatomi), perwajahan sampul, daya tarik, tipografi, dan ilustrasi), ukuran buku, kesesuaian jenis kertas dan keseuaian jenis kertas. ${ }^{14}$

\section{Pembahasan}

\section{Kualitas Buku Pegangan Guru}

Kualitas buku pegangan guru Bahasa Arab kelas XI kurikulum 2013 cetakan Kementerian Agama, memiliki kategori baik pada subkomponen kejelasan tahapan pembelajaran dan kejelasan kegiatan siswa. Dalam hal isi termuat pada setiap kali subbab/bab pembahasan materi. Guru sangat terbantu dengan penjelasan pembelajaran yang sangat rinci dalam bagian petunjuk khusus. Dengan demikian, proses belajar mengajar dapat berjalan sesuai dengan rincian kegiatan yang telah diuraikan pada bagian petunjuk khusus.

Selain itu, penyajian buku berada pada kategori baik. Buku menyertakan pendahuluan pada awal setiap sub-bab/bab, konsisten dalam penyajian sistematika pada setiap subbab/bab, dan berbasis aktivitas. Sementara itu, komponen penilaian pada buku Bahasa Arab pegangan guru kelas XI kurikulum 2013 cetakan Kementerian Agama memuat petunjuk secara jelas kegiatan penilaian yang dilakuakan guru selama proses pembelajaran. Selain itu, buku pegangan guru memuat aktivitas yang mengambarkan penilaian kepada siswa yang mencangkup penilaian pengetahuan, sikap, dan keterampilan atau unjuk kerja. Dalam hal grafik buku Bahasa Arab pegangan guru kelas XI kurikulum 2013 cetakan Kementerian Agama memiliki kualitas yang baik dalam penggunaan jenis kertas yang cukup tebal sehingga tidak menyebabkan tulisan yang ada di belakang halaman terlihat dari depan.

${ }^{14}$ Departemen Pendidikan Nasional, Standar Penilaian buku ajar, (Jakarta; Pusbuk, 2005), hal. 
Dalam Bab 1 dalam buku Bahasa Arab kelas XI Kurikulum 2013 Cetakan Kementerian Agama pegangan guru isi materi pembahasan adalah امال المراهقين didalam bahasa arab terdapat empat keterampilan diantaranya keterampilan mendengar, keterampilan membaca, keterampilan berbicara dan keterampilan menulis. Dari keempat keterampilan tersebut terdapat beberapa keterampilan yang saling melengkapi dari buku Bahasa Arab kelas XI Kurikulum 2013 Cetakan Kementerian Agama, pegangan guru maupun siswa.

Ada beberapa isi materi yang terdapat dibuku Bahasa Arab kelas XI Kurikulum 2013 Cetakan Kementerian Agama pegangan guru yang tidak terdapat pada buku Bahasa Arab kelas XI Kurikulum 2013 Cetakan Kementerian Agama pegangan siswa, di antaranya adalah isi materi keterampilan berbahasa mendengarkan yang mana isi materi tersebut hanya terdapat pada buku guru, dikarenakan didalam buku Bahasa Arab kelas XI Kurikulum 2013 Cetakan Kementerian Agama pegangan siswa terdapat keterangan atau penjelasan yang memyebutkan siswa mengikuti guru atau mendengarkan guru dalam melaksanakan atau mempelajari materi tersebut.

Selain itu, ada juga materi keterampilan berbicara yang mana terdapat susunan yang sangat runtut untuk menyampaikan isi materi dalam keterampilan berbicara sebagai pegangan guru yang mana dalam menyampaikan materi keterampilan berbicara, yang menjadikan proses belajar mengajar berjalan dengan lancar dan mencapai tujuan pembelajaran.

Adapun dalam keterampilan menulis, isi materi pada buku Bahasa Arab kelas XI Kurikulum 2013 Cetakan Kementerian Agama terdapat pada buku pegangan guru ataupu buku pegangan siswa akan tetapi didalam buku pegangan guru tidak hanya isi materi saja akan tetapi juga terdapat kunci jawaban dari soal-soal yang terdapat pada buku pegangan siswa.

Akan tetapi, terkesan buku pegangan guru merupakan kunci jawaban untuk latihan-latihan soal yang ada pada buku pegangan siswa. Hal ini pada akhirnya membunuh kreativitas guru untuk mengembangkan kemampuan kognisi dan psikomotorik dalam memecahkan masalah.

\section{Kualitas Buku Pegangan Siswa}

Hasil temuan menunjukkan kualitas buku Bahasa Arab pegangan siswa kelas XI kurikulum 2013 cetakan Kementerian Agama memiliki kategori baik, dalam isi yang berkaitan dengan pemberian kharokat, hal ini membantu siswa dalam hal 
membaca. Dalam hal penyajian, menyajikan tujuan pembelajaran KI dan KD pada setiap awal bab sehingga memudahkan dalam mengarahkan pembelajaran. Kemudian Bahasa, perintah yang digunakan halus, komunikatif, dan jelas. Sementara itu, dalam hal grafik, memiliki kualitas yang baik dalam penggunaan jenis kertas yang cukup tebal sehingga tidak menyebabkan tulisan yamg ada dibelakang halaman terlihat dari depan.

Dalam Bab 1 dalam buku Bahasa Arab kelas XI Kurikulum 2013 Cetakan Kementerian Agama pegangan siswa isi materi pembahasan adalah امال المراهقين didalam bahasa arab terdapat empat keterampilan diantaranya keterampilan mendengar, keterampilan membaca, keterampilan berbicara dan keterampilan menulis.

Dari kempat keterampilan tersebut ada beberapa isi materi pembahasan yang tidak terdapat didalam buku pegangan guru akan tetapi terdapat pada buku pegangan siswa. Seperti halnya keterampilan membaca, dalam buku Bahasa Arab pegangan siswa kelas XI kurikulum 2013 cetakan Kementerian Agama isi materi tersebut hanya terdapat pada buku siswa didalam buku pegangan guru tidak ada pembahasan isi materi keterampilan membaca dengan dalih alasan antara buku Bahasa Arab pegangan siswa kelas XI kurikulum 2013 cetakan Kementerian Agama pegangan siswa dan guru adalah berjalan selaras dan saling melengkapi.

Akan tetapi dalam keterampilan menulis di dalam buku Bahasa Arab pegangan siswa kelas XI kurikulum 2013 cetakan Kementerian Agama pegangan siswa maupun pegangan guru terdapat isi materi atau pembahasan yang sama dan saling melengkapi, dari sini bisa ditarik kesimpulan bahwa buku Bahasa Arab pegangan siswa kelas XI kurikulum 2013 cetakan Kementerian Agama pegangan siswa maupun pegangan guru saling melengkapi.

Namun, buku Bahasa Arab pegangan siswa kelas XI kurikulum 2013 cetakan Kementerian Agama tidak terdapat sumber rujukan berbasis situs teknologi informasi dan komunikasi pada gambar dalam pembahasan materi.

\section{Simpulan}

Berdasarkan analisis yang telah dilakukan, maka dapat disimpulkan bahwa kualitas buku Bahasa Arab pegangan guru kelas XI kurikulum 2013 cetakan Kementerian Agama, dan kualitas buku pegangan siswa kelas XI kurikulum 2013 cetakan Kementerian Agama, termasuk pada kategori baik. Hal ini dikarenakan sudah 
memenuhi standar yang ditetapkan oleh BSNP. Namun ada beberapa kekurangan dari buku Bahasa Arab pegangan guru kelas XI kurikulum 2013 cetakan Kementerian Agama, dan buku pegangan siswa kelas XI kurikulum 2013 cetakan Kementerian Agama, seperti halnya terdapat kunci jawaban latihan-latihan soal yang ada pada buku pegangan siswa didalam buku pegangan guru. Hal ini pada akhirnya membunuh kreativitas guru untuk mengembangkan kemampuan kognisi dan psikomotorik dalam memecahkan masalah. Dan juga pada buku Bahasa Arab pegangan siswa kelas XI kurikulum 2013 cetakan Kementerian Agama tidak terdapat sumber rujukan berbasis situs teknologi informasi dan komunikasi pada gambar dalam pembahasan materi.

\section{Daftar Pustaka}

Departemen Pendidikan Nasional, Pedoman Memilih dan Menyusun Bahan Ajar, (Jakarta: Dirjen Pendidikan Dasar dan Menengah, 2006)

Departemen Pendidikan Nasional, Standar Penilaian Buku Ajar, (Jakarta; Pusbuk, 2005)

Direktorat Pendidikan Menengah Umum, Pedoman memilih buku SMA (Jakarta:

Direktorat Pendidikan Menengah Umum, Direktorat Jenderal Manajemen Pendidikan Dasar dan Menengah, Departemen Pendidikan Nasional, 2004)

Hermawan, Acep. "Metodologi Pembelajaran Bahasa Arab, Cet Ke-1, Bandung: PT." Remaja Rosdakarya, 2011.

Lexy, J Moleong. "Metodologi Penelitian Kualitatif." Bandung: Remaja Rosdakarya, 2002.

Majid, Abdul. "Perencanaan Pembelajaran Mengembangkan Standar Kompetensi Guru." Bandung: PT Remaja Rosdakarya, 2008.

Mansur, Muslich. "Text Book Writing: Dasar-Dasar Pemahaman, Penulisan Dan Pemakaian Buku Teks.” Jogjakarta: Ar-Ruzz Media, 2010.

Mujib, Ahmad, and Muhammad Noval Rikza. "Tadriis Al-Nahw Fii Dhau AlNadzhariyyat Al-Ma'rifiyyat Li Thullaab Al-Shaff Al-Raabi' Bi Ma'had Daar AlNajaa Al-Islaamiyy Al-Salafiyy Ponorogo." Tsaqofiya: Jurnal Pendidikan Bahasa Dan Sastra Arab 1, no. 2 (2019): 69-84.

Mukarromah, Muhimmatul. "Tathwiir Al-Kitaab Al-Madrasiyy Li Al-Qawaaid Al'Arabaiyyat Li Thullaab Qism Ta'liim Al-Lughat Al-'Arabiyyat Bi Al-Jaami'ah." Tsaqofiya: Jurnal Pendidikan Bahasa Dan Sastra Arab 1, no. 2 (2019): 51-68. 
TSAQOFIYA: Jurnal Pendidikan Bahasa dan Sastra, 3 (1), 2021

Muslich, Masnur. "Text Book Writing: Dasar-Dasar Pemahaman, Penulisan, Dan Pemakaian Buku Teks." Jogjakarta: Ar-Ruzz Media 52 (2010): 47-52.

Prastowo, Andi. Panduan Kreatif Membuat Bahan Ajar Inovatif. Yogyakarta: Diva Press, 2011.

Supriadi, Dedi, and Hermawan S Nugroho. Anatomi Buku Sekolah Di Indonesia: Problematik Penilaian, Penyebaran, Dan Penggunaan Buku Pelajaran, Buku Bacaan, Dan Buku Sumber. -, 1919.

Tarigan, Henry Guntur, and Djago Tarigan. Telaah Buku Tekst Bahasa Indonesia. Angkasa, 1986. 